\title{
Chemoprevention of cancer: current evidence and future
}

\section{prospects [version 1; peer review: 3 approved]}

\author{
Vassiliki Benetou1 ${ }^{1}$, Areti Lagiou2, Pagona Lagiou 1,3 \\ ${ }^{1}$ Department of Hygiene, Epidemiology and Medical Statistics, University of Athens Medical School, Athens, GR-115 27, Greece \\ ${ }^{2}$ Department of Public Health and Community Health, Faculty of Health Professions, Athens Technological Educational Institute (TEI \\ Athens), Athens, Greece \\ ${ }^{3}$ Department of Epidemiology, Harvard School of Public Health, Boston, MA, USA
}

V1 First published: 28 Sep 2015, 4(F1000 Faculty Rev):916

https://doi.org/10.12688/f1000research.6684.1

Latest published: 28 Sep 2015, 4(F1000 Faculty Rev):916

https://doi.org/10.12688/f1000research.6684.1

\section{Abstract}

Cancer chemoprevention refers to the use of agents for the inhibition, delay, or reversal of carcinogenesis before invasion. In the present review, agents examined in the context of cancer chemoprevention are classified in four major categories-hormonal, medications, dietrelated agents, and vaccines-and the main representatives of each category are presented. Although there are serious constraints in the documentation of effectiveness of chemopreventive agents, mainly stemming from the long latency of the condition they are addressing and the frequent lack of intermediate biomarkers, there is little disagreement about the role of aspirin, whereas a diet rich in vegetables and fruits appears to convey more protection than individual micronutrients. Among categories of cancer chemopreventive agents, hormonal ones and vaccines might hold more promise for the future. Also, the identification of individuals who would benefit most from chemopreventive interventions on the basis of their genetic profiles could open new prospects for cancer chemoprevention.

\section{Keywords}

Cancer, chemoprevention, aspirin, nutrients, supplements, antiestrogens, antiandrogens, SERMs, aromatase inhibitors, vaccines, HBV, HPV

\section{Open Peer Review}

Approval Status

1

2

3

version 1

28 Sep 2015

Faculty Reviews are review articles written by the prestigious Members of Faculty Opinions. The articles are commissioned and peer reviewed before publication to ensure that the final, published version is comprehensive and accessible. The reviewers who approved the final version are listed with their names and affiliations.

1. Michihiro Mutoh, National Cancer Center,

Chuo-ku, Japan

2. Hasan Mukhtar, University of Wisconsin

Medical Science Center, Madison, USA

3. Janusz Jankowski, University of Warwick,

Warwickshire, UK

Any comments on the article can be found at the end of the article. 
Corresponding author: Vassiliki Benetou (vbenetou@med.uoa.gr)

Competing interests: The authors declare that they have no competing interests.

Grant information: The author(s) declared that no grants were involved in supporting this work.

Copyright: $\odot 2015$ Benetou V et al. This is an open access article distributed under the terms of the Creative Commons Attribution License, which permits unrestricted use, distribution, and reproduction in any medium, provided the original work is properly cited.

How to cite this article: Benetou V, Lagiou A and Lagiou P. Chemoprevention of cancer: current evidence and future prospects [version 1; peer review: 3 approved] F1000Research 2015, 4(F1000 Faculty Rev):916 https://doi.org/10.12688/f1000research.6684.1

First published: 28 Sep 2015, 4(F1000 Faculty Rev):916 https://doi.org/10.12688/f1000research.6684.1 


\section{Introduction}

Cancer is a leading cause of death worldwide, ranking second in economically developed countries ${ }^{1,2}$. With several forms of cancer being poorly controlled through treatments, which themselves have serious side effects, and with the unavoidable limitations of cancer screening programs, chemoprevention and its potential have generated much hope and interest during the last decades. Cancer chemoprevention is the inhibition or reversal of carcinogenesis (before invasion) by intervention with pharmacologically active agents $^{3}$. The concept was introduced by Sporn and colleagues in the mid-1970s ${ }^{4}$.

More than a decade ago, one of us (PL) contributed to an effort to summarize available options for chemoprevention and its potential ${ }^{5}$. In the present article, we examine the current evidence on chemopreventive agents and whether there has been any progress in terms of discovery or use of these agents in the context of cancer prevention.

\section{Cancer chemopreventive agents}

Cancer chemopreventive agents can be classified in four major categories: hormonal, medications, diet-related agents, and vaccines.

\section{A. Hormonal chemopreventive agents}

All hormonal chemopreventive agents are relevant to steroid-related cancers. They can be classified in two subcategories: antiestrogens and antiandrogens.

\section{a. Antiestrogens}

i. Selective estrogen receptor modulators. Selective estrogen receptor modulators (SERMs) form a diverse group of compounds that exhibit a varying level of tissue-specific estrogen receptor (ER) activity that can be antagonistic but also agonistic depending on the target tissue ${ }^{6,7}$. More specifically, SERMs exert an antagonistic activity on breast tissue and an agonist activity on skeletal system. Some SERMs have been reported to demonstrate an ER agonistic effect on the vagina and an antagonistic effect on the endometrium, the latter when combined with estrogen.

During the last decade, strong evidence on the effectiveness of SERMs for breast cancer prevention has accumulated ${ }^{8}$. A metaanalysis combining data from nine clinical trials and comparing use of SERMs (tamoxifen, raloxifene, arzoxifene, or lasofoxifene) with placebo reported a significant decrease in breast cancer incidence with treatment compounds, both during treatment and for at least 5 years after completion". The reduction in risk was confined to ER-positive invasive breast cancer (for all SERMs used) and ductal carcinoma in situ (for all, except raloxifene). Strengthening the evidence from the abovementioned meta-analysis, a recently updated analysis from the International Breast Cancer Intervention Study I (IBIS-I) provided evidence for a long-term protective effect of tamoxifen after its cessation, for at least 20 years after use ${ }^{10}$.

Risks associated with tamoxifen are increased occurrence of thromboembolic events, endometrial cancer, and all-cause mortality ${ }^{8,9,11}$. Raloxifene has been associated mainly with an increase in thromboembolic events. The risk-to-benefit ratio of treatment with tamoxifen or raloxifene depends on age, race, breast cancer risk, and history of hysterectomy. Over the course of a 5-year period, postmenopausal women with an intact uterus have been reported to have a better risk-to-benefit ratio for raloxifene compared with tamoxifen, whereas for postmenopausal women without a uterus the risk-to-benefit ratio was similar for the two compounds ${ }^{8,12}$. Notwithstanding the reported results on cancer incidence, overall breast cancer mortality has not been shown to decrease in chemoprevention trials with SERMs conducted so far, and consequently some are questioning their role in reducing the overall burden of breast cancer ${ }^{13}$.

ii. Aromatase inhibitors. Aromatase inhibitors (AIs) inhibit the enzyme aromatase, which catalyzes the aromatization procedure that converts androgens into estrogens. Recent data suggest that anastrozole and exemestane are both associated with reduced breast cancer incidence among women at increased risk for the disease ${ }^{8,14-16}$. They are well tolerated, although some researchers point out that careful monitoring of adverse effects related to joint pain and menopausal symptoms should be implemented in large clinical trials ${ }^{17,18}$. AIs can be used as an alternative chemoprevention agent for high-risk postmenopausal women who desire chemoprevention and have contraindications for SERM use ${ }^{14,19}$.

Regarding recommendations for the use of antiestrogens in breast cancer prevention, the American Society of Clinical Oncology practice guidelines indicate the administration of tamoxifen for 5 years in women 35 years and older at increased risk of breast cancer in order to reduce the risk of ER-positive breast cancer. In postmenopausal women, 5-year regimens with raloxifene or exemestane should also be discussed as options ${ }^{19}$. In the UK, the National Institute for Health and Care Excellence also provides detailed guidance on the use of tamoxifen or raloxifene for pre- or postmenopausal women who are at risk of familial breast cancer but who are not at increased risk of thromboembolic disease or endometrial cancer ${ }^{20}$.

Despite recommendations, the use of SERMs as primary prevention drugs for breast cancer in clinical practice is considered limited ${ }^{19-21}$. Several reasons have been invoked, including fear of adverse effects, the lack of reasonably accurate and feasible methods for assessing individual risk, the lack of a marker to monitor cancer risk reduction, insufficient public and professional information, and medication costs ${ }^{8}$.

\section{b. Antiandrogens}

Both testosterone and dihydrotestosterone (DHT) are essential for normal growth and functioning of the prostate. The role of antiandrogens in prostate cancer prevention relies on the hypothesis that androgens may be implicated in the etiology of prostate cancer and that suppressing DHT synthesis may inhibit carcinogenesis ${ }^{22}$. 5-alpha-reductase is the enzyme that converts testosterone to the more active intracellular androgen DHT; the antiandrogens 5-alpha-reductase inhibitors (5-ARIs) block the process by inhibiting this enzyme.

Two 5-ARIs, finasteride and dutasteride, have been tested as chemopreventive agents for prostate cancer. Two large randomized placebo-controlled trials, the Prostate Cancer Prevention Trial with finasteride and the Reduction by Dutasteride of Prostate Cancer Events (REDUCE), have reported a decreased incidence of 
low-grade prostate cancer; in both, however, an absolute increase in high-grade prostate cancer has also been observed ${ }^{23-25}$.

A meta-analysis of randomized clinical trials reported that 5-ARIs reduce the risk of prostate cancer among men who are screened regularly by using prostate-specific antigen (PSA) level ${ }^{26}$. The beneficial effects, however, were confined to men with PSA levels of less than $4.0 \mathrm{ng} / \mathrm{mL}$. Evidence was insufficient with respect to the optimal age to initiate treatment or duration of chemoprevention. Uncertainty was also expressed with respect to the impact of 5-ARIs on tumors with the greatest lethal potential, including those with Gleason scores of 8 to 10. In 2010, the US Food and Drug Administration (FDA) evaluated the results of trials and supported the conclusion drawn by the Oncologic Drugs Advisory Committee that finasteride and dutasteride do not have a favorable risk-to-benefit profile in order to be proposed for chemoprevention of prostate cancer among healthy men ${ }^{25}$.

\section{B. Medications}

In the past, only aspirin and other anti-inflammatory drugs would have been classified under this category of chemopreventive agents. More recently, however, interest has emerged about a potential cancer chemopreventive role of statins and metformin.

\section{a. Aspirin and other anti-inflammatory drugs}

Inflammation is linked to carcinogenesis and hence it is reasonable to assume that agents with anti-inflammatory effects, like the nonsteroidal anti-inflammatory drugs (NSAIDs), could have cancer chemopreventive properties. The main representative of NSAIDs is aspirin, but other compounds like indomethacin and piroxicam are included in this class of medications. Various hypotheses have been invoked to explain the chemopreventive properties of NSAIDs ${ }^{5,27}$. Most prominent among them is the hypothesis about cyclooxygenase (COX) inhibition. COX -1 and -2 are enzymes necessary for the synthesis of inflammatory prostaglandins from arachidonic acid, and NSAIDs inhibit these enzymes. COX-2 is believed to be overexpressed in the early stages of colon carcinogenesis. Selective COX-2 inhibitors have also been developed.

A large body of evidence, from both randomized trials and observational epidemiological studies, has strengthened the hypothesis that regular prophylactic aspirin use reduces incidence of and mortality from colorectal cancer in the general population. A favorable effect of aspirin has also been reported with respect to recurrence of adenomatous polyps as well as polyp load in individuals with hereditary colon cancer ${ }^{27-31}$. Although data are less extensive, studies have shown reductions in incidence of and mortality from esophageal, stomach, and other gastrointestinal cancers as well as inverse, though small in magnitude, associations with breast, prostate, and lung cancers ${ }^{27}$.

Issues that remain to be clarified are the optimal dose and duration of use and appropriate ages for use in average-risk individuals. Reduced incidence and mortality have been seen for all daily doses of above $75 \mathrm{mg}$, but there is no clear indication of a greater reduction with increasing dose $\mathrm{e}^{32}$. In a recent systematic review, the authors concluded that prophylactic aspirin use for at least 5 years at daily doses ranging from 75 to $325 \mathrm{mg}$, starting between ages 50 and 65 , has a favorable risk-to-benefit profile for cancer prevention in the average-risk general population in the developed world for both sexes. Larger benefits were observed for 10-year use, whereas longer use still seems beneficial ${ }^{33}$.

Nevertheless, benefits need to be balanced against harms. The side effects of aspirin and NSAIDs, attributed to inhibition of COX-1 activity in platelets, include gastrointestinal track bleeding and intracranial or extracranial hemorrhage, but serious incidents are not common at ages of less than 70 years ${ }^{27,34}$. Overall, it seems important for evidence-based recommendations regarding the use of aspirin in chemoprevention to be integrated with those for cardiovascular disease prevention.

\section{b. Statins}

Statins (3-hydroxy-3-methylglutaryl coenzyme A reductase inhibitors) are used as cholesterol-lowering drugs but have also drawn attention as potential cancer chemopreventive agents ${ }^{35-37}$. Reduction of mevalonate synthesis by inhibiting 3-hydroxy-3-methylglutaryl coenzyme A reductase has been invoked as a possible mechanism for a statin-induced suppression of tumor growth, induction of apoptosis, and inhibition of angiogenesis ${ }^{38,39}$.

In a meta-analysis of 40 studies, a modest decrease in colorectal cancer risk with statin use was observed, which, however, was statistically significant among observational studies but not among randomized controlled trials ${ }^{40}$. Reports for reduction of risk with respect to other cancer sites, such as prostate and gastric cancer as well as esophageal cancer (especially adenocarcinoma among patients with Barrett's esophagus), have also appeared in the literature $37,41,42$.

Overall, however, there is currently no conclusive evidence for a cancer chemopreventive effect of statins ${ }^{37,43}$. Of note, statin use among cancer patients before diagnosis has been associated with reduced total and site-specific mortality ${ }^{44}$.

\section{c. Metformin}

Metformin is a commonly prescribed drug for type 2 diabetes and belongs in the biguanide class. The crucial role of energy metabolism in cell growth and proliferation implies that antidiabetic or metabolism-altering drugs may hold preventive and therapeutic value, and, in this context, mechanisms for a potential cancer preventive effect of metformin have been proposed ${ }^{45}$.

Epidemiologic studies indicate that diabetics treated with metformin have a decreased cancer risk compared with those on other antidiabetic medications ${ }^{46,47}$. Although evidence of a cancer chemopreventive effect of metformin among diabetics is accumulating, the question remains as to whether metformin can exert similar beneficial effects in non-diabetics ${ }^{45,48,49}$.

\section{Diet-related agents}

Several micronutrients have attracted the attention of the scientific community as potential cancer-preventive agents. Among them, diet-derived antioxidants have been studied intensively on account of the protection they convey against oxidative stress. Current evidence on chemopreventive effects of antioxidants and other micronutrients is summarized below. 


\section{a. Carotenoids}

Carotenoids are fat-soluble red/orange pigments with antioxidant properties and comprise more than 600 compounds. Of the approximately 50 found in human diets, only about half can be absorbed. Carotenoids are found in vegetables and include xanthophylls (e.g., lutein) and carotenes (e.g., beta-carotene and lycopene). Betacarotene and other carotenoids can be converted to retinol and therefore are referred to by some as "pro-vitamin A"

Beta-carotene is one of the most studied carotenoids. Observational epidemiologic studies have shown a beneficial effect of betacarotene dietary intake on cancer prevention, but large clinical trials conducted during the 1990s did not confirm these findings; on the contrary, they demonstrated a detrimental effect. Thus, in the Alpha-Tocopherol Beta-Carotene (ATBC) Cancer Prevention Study, beta-carotene supplementation was associated with an increase in lung cancer risk as well as in risk of other cancers, notably prostate and stomach ${ }^{51}$. Similarly, in the Beta-Carotene and Retinol Efficacy Trial (CARET), beta-carotene and retinol supplementation were found to increase lung cancer risk ${ }^{52}$. Overall, the evidence about a protective effect of foods rich in carotenoids against cancers of the mouth, lung, pharynx, and larynx as well as about a protective effect of foods rich in beta-carotene against esophageal cancer is evaluated as probable; there is, however, strong evidence that betacarotene supplements are associated with lung cancer in current smokers ${ }^{50,53}$, which has been classified as "convincing" in the second expert report of the World Cancer Research Fund and the American Institute for Cancer Research ${ }^{50}$. Among other carotenoids, dietary lycopene (mainly found in tomatoes) has been inversely associated with prostate cancer risk, but the level of evidence has been downgraded from probable ${ }^{50}$ to limited ${ }^{54}$.

\section{b. Vitamin A and retinoids}

Vitamin A or retinol is the best known retinoid. Retinoids are required for the maintenance of normal cell growth and differentiation; together with their dietary precursor (beta-carotene), they were some of the first agents to be tested in large population-based trials $^{55}$. The CARET trial in the United States studied beta-carotene along with retinol among smokers and did not show benefit from retinol (nor for beta-carotene) supplementation ${ }^{52}$. Both the ATBC and the CARET trials found a significant increase in lung cancer incidence in the retinol/beta-carotene-containing $\operatorname{arms}^{56}$.

\section{c. Folic acid}

Folic acid or folate, a water-soluble vitamin B, is an important cofactor in one-carbon metabolism. Folate appears to possess dual modulatory effects on colorectal carcinogenesis depending on timing and dosage. In normal colorectal mucosa folate deficiency appears to enhance neoplastic transformation, modest levels of folic acid supplementation appear to suppress, whereas high supplemental doses appear to enhance the development of cancer. Of note, folate deficiency appears also to inhibit whereas folate supplementation has a promoting effect on the progression of established colorectal neoplasms $\mathrm{s}^{57}$. On the basis of a lack of compelling supportive evidence from studies in humans and its potential tumor-promoting effect, folic acid supplementation cannot currently be recommended for colorectal cancer chemoprevention. The evidence concerning the inverse association of dietary folate intake with pancreatic cancer has been downgraded from probable ${ }^{50}$ to limited ${ }^{58}$.

\section{d. Vitamin C}

Vitamin $\mathrm{C}$ is a water-soluble antioxidant and enzyme cofactor. Humans do not have the ability to synthesize it and must obtain it through diet. Vitamin $\mathrm{C}$ has two chemical forms, one reduced (ascorbic acid) and one oxidized (dehydroascorbic acid) form.

In 1997, expert panels at the World Cancer Research Fund (WCRF) and the American Institute for Cancer Research had concluded that dietary vitamin $\mathrm{C}$ could reduce the risk of the stomach (probably) as well as mouth, pharynx, esophagus, lung, pancreas, and cervical cancers (possibly), but in their updated report in 2007, only the evidence with respect to esophageal cancer was considered probable and there was no evidence that vitamin $\mathrm{C}$ supplementation modifies the risk of cancer ${ }^{50,59}$. Recently, in a large-scale clinical trial in men, vitamin $\mathrm{C}$ supplementation had no immediate or long-term effects on the risk of prostate or other site-specific cancers or total cancer ${ }^{60}$.

\section{e. Vitamin D}

Vitamin D plays an important role in calcium metabolism but also exerts various other physiological functions. Experimental studies have shown that many cell types, including colorectal cells, express vitamin $\mathrm{D}$ receptors, and activation of these receptors by $1,25(\mathrm{OH})_{2} \mathrm{D}(1,25$-dihydroxycholecalciferol or calcitriol) has been reported to exert antitumor effects ${ }^{61}$.

In 2008, the International Agency for Research on Cancer (IARC) Working Group on Vitamin D, having examined the evidence on various cancer sites, concluded that evidence from observational studies for an inverse association between serum 25-hydroxyvitamin D levels and the incidence of colorectal cancer and sporadic colorectal adenomas was consistent and persuasive, but there was only limited evidence of a causal association and this was due to possible confounding by other dietary or lifestyle factors. Results from randomized trials to that date had not demonstrated an effect of vitamin D supplementation on colorectal cancer risk but could not be judged as contradictory to the evidence from observational studies, either ${ }^{62}$. Hence, there have been suggestions for a minimum vitamin D intake in the context of colorectal cancer prevention ${ }^{61}$.

\section{f. Vitamin E}

Vitamin $\mathrm{E}$ is a fat-soluble vitamin with antioxidant activity. It refers to a group of compounds that include both tocotrienols and tocopherols, among which $\alpha$-tocopherol is the most biologically active.

In the ATBC trial, an inverse association between vitamin E supplementation and prostate cancer was reported but it disappeared post-interventionally ${ }^{63,64}$. Null results for vitamin E supplementation were also reported in the Physicians' Health Study with respect to prostate as well as overall cancer ${ }^{60}$. In the Selenium and Vitamin E Cancer Prevention Trial (SELECT) in men, vitamin E, alone or in combination with selenium, was not associated with a reduction in prostate cancer risk; a subsequent report even noted an increase in the risk of prostate cancer among those who received vitamin $\mathrm{E}^{65,66}$. Hence, current evidence does not support the use of vitamin $\mathrm{E}$ for cancer prevention ${ }^{67}$.

\section{g. Calcium}

Calcium is an essential nutrient and plays an important role in muscular contraction, cellular growth, cell adhesion, and bone formation. 
Results from large observational studies support a relatively consistent inverse association of calcium intake with colorectal adenomas and colorectal cancer ${ }^{61,68}$. This effect is thought to be exerted by binding to toxic secondary bile acids and ionized fatty acids to form insoluble soaps in the lumen of the colon or by directly reducing proliferation, stimulating differentiation, and inducing apoptosis in the colonic mucosa ${ }^{69}$.

In a systematic review and meta-analysis, supplemental calcium was reported to be effective for the prevention of adenoma recurrence in populations with a history of adenomas, but no association was found for colorectal cancer ${ }^{70}$.

There is some concern that a high calcium intake may increase prostate cancer incidence. The evidence on diets high in calcium or dairy products is considered as limited but suggestive, whereas the evidence on calcium supplements has been downgraded from probable to limited, on the basis of which no conclusions can be drawn $^{50,54}$.

\section{h. Selenium}

Selenium is an essential cofactor for the major antioxidant enzyme glutathione peroxidase, which protects against oxidative damage to lipids, lipoproteins, and DNA ${ }^{50,71}$. The results of the SELECT clinical trial did not provide encouraging data for prostate cancer prevention $^{65}$. Also, a more recent phase III study of selenium versus placebo in patients with high-grade prostatic intraepithelial neoplasia found no benefit in the prevention of progression to prostate cancer and even suggested that higher intake might increase the risk of cancer $^{72}$. In its updated report of 2014 on prostate cancer, the WCRF concluded that there is limited suggestive evidence that low plasma concentrations of selenium are associated with increased prostate cancer risk, but no conclusions can be drawn on the basis of the existing evidence for selenium supplementation ${ }^{54}$.

\section{i. Flavonoids}

Flavonoids are polyphenolic compounds that inhibit carcinogenactivating enzymes and possess various antioxidant properties. More than 5,000 individual flavonoids have been identified and have been classified into subclasses on the basis of their range and structural complexity. Fruits and vegetables, along with tea and wine, are the main dietary sources of flavonoids ${ }^{73}$.

Epidemiologic data, though not conclusive, suggest a protective role of flavonoids on particular cancer types, such as lung, breast, colon, and prostate ${ }^{73-78}$. In a meta-analysis of observational studies, flavonol and flavone intake, but not other flavonoid subclass or total flavonoid intake, were associated with a decreased breast cancer risk, especially among post-menopausal women ${ }^{79}$. With respect to colorectal cancer, evidence on the role of flavonoid intake was judged to be insufficient and conflicting ${ }^{80}$. Evidence on a potential chemopreventive role of various polyphenols, such as isoflavones, on prostate cancer risk has also been reported ${ }^{81-83}$.

\section{j. Multivitamin/multimineral supplements}

In 2007, the National Institutes of Health, in a State-of-the-Science statement on multivitamin/multimineral supplements and chronic disease prevention, indicated that data are scarce on the efficacy and safety of multivitamin and mineral supplement use in primary prevention of chronic diseases in the general adult population. Specifically for cancer, though the statement recognized a potential benefit among persons with poor nutritional status or suboptimal antioxidant intake, it concluded that use of multivitamin supplements by the general population was not supported by the existing scientific evidence $^{84}$. In 2013, a meta-analysis of randomized controlled trials concluded that multivitamin/multimineral use had no effect on cancer prevention ${ }^{85}$. Of note, the expert panels of the WCRF report concluded that the evidence from its review of trials did not show that micronutrient supplements have any benefits in cancer survivors, whereas high-dose supplements may even be harmful ${ }^{50}$.

\section{Vaccines for cancer prevention}

Several infections have been linked to increased cancer risk; however, only two vaccines against infectious agents are currently used in clinical practice for the prevention of cancer: the vaccine against the hepatitis B virus (HBV) and the vaccine against human papilloma virus $(\mathrm{HPV})^{86,87}$.

The HBV vaccine was developed in the late 1960s. The first commercial vaccine was circulated in the early 1980s; genetically engineered vaccines were developed in the late 1980s and these vaccines are the ones currently used. Chronic HBV infection is a major cause of hepatocellular carcinoma, and by preventing the infection and chronic carriage state, the HBV vaccine provides protection against hepatocellular carcinoma ${ }^{88}$.

HPV vaccination was introduced much later than $\mathrm{HBV}$ vaccination. The first HPV vaccine was approved by the FDA in the mid-2000s. There are more than $40 \mathrm{HPV}$ types that infect human mucosal surfaces, but most infections are asymptomatic and transient. However, certain oncogenic types that persist can cause cervical cancer and other, less common, cancers, including cancers of the anus, penis, vulva, vagina, and oropharynx. Other, non-oncogenic HPV types can cause genital warts ${ }^{89,90}$. Two preventive HPV vaccines, one quadrivalent (which protects against types 16, 18, 6, and 11) and one bivalent (which protects against types 16 and 18), are currently used, but research for new vaccines that will protect against more oncogenic types of the virus is ongoing ${ }^{91}$. Although history of use of this vaccine is not long, current evidence suggests that it is both effective and safe ${ }^{91,92}$.

\section{Conclusions}

The concept of chemoprevention is intuitively attractive as it implies avoidance of suffering caused by the diagnosis of cancer, the disease itself, and its treatment. There are, however, serious constraints in the documentation of effectiveness of chemopreventive agents for cancer ${ }^{11,95}$, mainly stemming from the long latency of the condition they are addressing. Cancer latency is in the range of years and is certainly longer than the duration of the clinical trials designed to address the effectiveness of cancer chemopreventive agents. The problem could be bypassed with the use of intermediate biomarkers, but these are frequently lacking. Of note, trials assessing the effectiveness of chemopreventive agents have to rely on changes in the incidence of cancer in a population, and this is a rare event, even among high-risk population groups. Other limitations in the documentation of effectiveness of chemopreventive agents are related to 
the preservation of bioactivity of the various compounds following digestion as well as to the determination of the appropriate effective dose. Furthermore, because chemoprevention refers to the widespread and long-term use of compounds by the general "healthy" population, safety is an issue of paramount importance that needs to be addressed in studies with long follow-up in large segments of the population in order to be able to identify even rare side effects.

Although the opinions about the potential of cancer chemoprevention vary widely in the literature, there is little disagreement about the role of aspirin, whereas a diet rich in vegetables and fruits appears to convey more protection than individual micronutrients ${ }^{11,93-95}$. Among categories of chemopreventive agents, hormonal ones and vaccines used for cancer prevention might hold more promise for the future. Also, the potential of differential effectiveness of chemopreventive agents by particular genotypes ${ }^{96}$ is extremely intriguing and could open new prospects for cancer chemoprevention.

\section{Competing interests}

The authors declare that they have no competing interests.

Grant information

The author(s) declared that no grants were involved in supporting this work.
1. World Cancer Report 2014. Stewart BW and Wild CP, Eds. IARC (WHO). Lyon, France: 2014. Reference Source

2. Ferlay J, Soerjomataram I, Ervik M, et al: GLOBOCAN 2012 v1.0, Cancer Incidence and Mortality Worldwide: IARC Cancer Base No. 11 [Internet]. Lyon, France: International Agency for Research on Cancer; 2013.

3. Biomarkers in Cancer Chemoprevention. IARC Scientific Publications No. 154. Eds Miller AB, Bartsch H, Boffeta P, Dragsted L, and Vainio H. International Agency for Cancer Research. Lyon, 2001. Reference Source

4. Sporn MB, Dunlop NM, Newton DL, et al:: Prevention of chemical carcinogenesis by vitamin A and its synthetic analogs (retinoids). Fed Proc. 1976; 35(6): 1332-8. PubMed Abstract

5. Tamimi RM, Lagiou P, Adami HO, et al:: Prospects for chemoprevention of cancer. J Intern Med. 2002; 251(4): 286-300.

PubMed Abstract | Publisher Full Text

6. Mirkin S, Pickar JH: Selective estrogen receptor modulators (SERMs): a review of clinical data. Maturitas. 2015; 80(1): 52-7. PubMed Abstract | Publisher Full Text

7. Martinkovich S, Shah D, Planey SL, et al:: Selective estrogen receptor modulators: tissue specificity and clinical utility. Clin Interv Aging. 2014; 9 1437-52.

PubMed Abstract | Publisher Full Text | Free Full Text

8. Vogel VG: Role of hormones in cancer prevention. Am Soc Clin Oncol Educ Book. 2014; 34-40.

PubMed Abstract | Publisher Full Text

9. F Cuzick J, Sestak I, Bonanni B, et al:: Selective oestrogen receptor modulators in prevention of breast cancer: an updated meta-analysis of individual participant data. Lancet. 2013; 381(9880): 1827-34. PubMed Abstract | Publisher Full Text | Free Full Text | F1000 Recommendation

10. F Cuzick J, Sestak I, Cawthorn S, et al:: Tamoxifen for prevention of breast cancer: extended long-term follow-up of the IBIS-I breast cancer prevention trial. Lancet Oncol. 2015; 16(1): 67-75. PubMed Abstract | Publisher Full Text | F1000 Recommendation

11. Potter JD: The failure of cancer chemoprevention. Carcinogenesis. 2014; 35(5): 974-82.

PubMed Abstract | Publisher Full Text

12. F Vogel VG, Costantino JP, Wickerham DL, et al:: Update of the National Surgical Adjuvant Breast and Bowel Project Study of Tamoxifen and Raloxifene (STAR) P-2 Trial: Preventing breast cancer. Cancer Prev Res (Phila). 2010; 3(6): 696-706.

PubMed Abstract | Publisher Full Text | Free Full Text | F1000 Recommendation

13. Cameron DA: Breast cancer chemoprevention: little progress in practice? Lancet. 2014; 383(9922): 1018-20. PubMed Abstract | Publisher Full Text

14. Olin JL, St Pierre M: Aromatase inhibitors in breast cancer prevention. Ann Pharmacother. 2014; 48(12): 1605-10. PubMed Abstract | Publisher Full Text
15. F Goss PE, Ingle JN, Alés-Martínez JE, et al.: Exemestane for breast-cancer prevention in postmenopausal women. N Engl J Med. 2011; 364(25): 2381-91. PubMed Abstract | Publisher Full Text | F1000 Recommendation

16. F Cuzick J, Sestak I, Forbes JF, et al.: Anastrozole for prevention of breast cancer in high-risk postmenopausal women (IBIS-II): an international, double-blind, randomised placebo-controlled trial. Lancet. 2014; 383(9922): 1041-8.

PubMed Abstract | Publisher Full Text | F1000 Recommendation

17. F Maunsell E, Goss PE, Chlebowski RT, et al:: Quality of life in MAP.3 (Mammary Prevention 3): a randomized, placebo-controlled trial evaluating exemestane for prevention of breast cancer. J Clin Oncol. 2014; 32(14): 1427-36. PubMed Abstract | Publisher Full Text | F1000 Recommendation

18. Niravath $P$, Rimawi MF, Osborne CK: Aromatase inhibitor adverse effects: are we sweeping them under the rug? J Clin Oncol. 2014; 32(33): 3779. PubMed Abstract | Publisher Full Text

19. Visvanathan $\mathrm{K}$, Hurley $\mathrm{P}$, Bantug $\mathrm{E}$, et al:: Use of pharmacologic interventions for breast cancer risk reduction: American Society of Clinical Oncology clinical practice guideline. J Clin Oncol. 2013; 31(23): 2942-62. PubMed Abstract | Publisher Full Text

20. Evans DG, Graham J, O'Connell S, et al:: Familial breast cancer: summary of updated NICE guidance. BMJ. 2013; 346: 33829. PubMed Abstract | Publisher Full Text

21. Waters EA, McNeel TS, Stevens WM, et al:: Use of tamoxifen and raloxifene for breast cancer chemoprevention in 2010. Breast Cancer Res Treat. 2012; 134(2): 875-80.

PubMed Abstract | Publisher Full Text | Free Full Text

22. Mucci LA, Signorello LB, Adami HO: Prostate cancer. In Textbook of Cancer Epidemiology. $2^{\text {nd }}$ edition. Edited by Adami HO, Hunter D \& Trichopoulos D. Oxford: University Press; 2008; 517-555. Publisher Full Text

23. F Thompson IM, Goodman PJ, Tangen CM, et al:: The influence of finasteride on the development of prostate cancer. N Engl J Med. 2003; 349(3): 215-24. PubMed Abstract | Publisher Full Text | F1000 Recommendation

24. Madersbacher S: Words of wisdom. Re: Effect of dutasteride on the risk of prostate cancer. Andriole GL, Bostwick DG, Brawley OW, et al. REDUCE Study Group. N Engl J Med 2010;362:1192-202. Eur Urol. 2010; 58(2): 312. PubMed Abstract | Publisher Full Text

25. F Theoret MR, Ning YM, Zhang JJ, et al.: The risks and benefits of 5a-reductase inhibitors for prostate-cancer prevention. N Engl J Med. 2011 365(2): 97-9.

PubMed Abstract | Publisher Full Text | F1000 Recommendation

26. F Wilt TJ, Macdonald R, Hagerty K, et al.: 5- $\alpha$-Reductase inhibitors for prostate cancer chemoprevention: an updated Cochrane systematic review. BJU Int. 2010; 106(10): 1444-51.

PubMed Abstract | Publisher Full Text | F1000 Recommendation

27. Thorat MA, Cuzick J: Role of aspirin in cancer prevention. Curr Oncol Rep. 2013; 15(6): 533-40.

PubMed Abstract | Publisher Full Text 
28. Chan AT, Arber N, Burn J, et al.: Aspirin in the chemoprevention of colorectal neoplasia: an overview. Cancer Prev Res (Phila). 2012; 5(2): 164-78. PubMed Abstract | Publisher Full Text | Free Full Text

29. F Cole BF, Logan RF, Halabi S, et al:: Aspirin for the chemoprevention of colorectal adenomas: meta-analysis of the randomized trials. J Nat/ Cancer Inst. 2009; 101(4): 256-66.

PubMed Abstract | Publisher Full Text | F1000 Recommendation

30. Burn J, Bishop DT, Chapman PD, et al:: A randomized placebo-controlled prevention trial of aspirin and/or resistant starch in young people with familial adenomatous polyposis. Cancer Prev Res (Phila). 2011; 4(5): 655-65. PubMed Abstract | Publisher Full Text | Free Full Text

31. F Ishikawa H, Mutoh M, Suzuki S, et al.: The preventive effects of low-dose enteric-coated aspirin tablets on the development of colorectal tumours in Asian patients: a randomised trial. Gut. 2014; 63(11): 1755-9. PubMed Abstract | Publisher Full Text | F1000 Recommendation

32. F Rothwell PM, Wilson M, Elwin CE, et al.: Long-term effect of aspirin on colorectal cancer incidence and mortality: 20-year follow-up of five randomised trials. Lancet. 2010; 376(9754): 1741-50. PubMed Abstract | Publisher Full Text | F1000 Recommendation

33. F Cuzick J, Thorat MA, Bosetti C, et al.: Estimates of benefits and harms of prophylactic use of aspirin in the general population. Ann Oncol. 2015; 26(1): $47-57$.

PubMed Abstract | Publisher Full Text | Free Full Text | F1000 Recommendation

34. Ikeda $\mathrm{Y}$, Shimada $\mathrm{K}$, Teramoto $\mathrm{T}$, et al:: Low-dose aspirin for primary prevention of cardiovascular events in Japanese patients 60 years or older with atherosclerotic risk factors: a randomized clinical trial. JAMA. 2014; 312(23): $2510-20$.

PubMed Abstract | Publisher Full Text

35. Chan KK, Oza AM, Siu LL: The statins as anticancer agents. Clin Cancer Res. 2003; 9(1): 10-9. PubMed Abstract

36. Singh PP, Singh S: Statins - the Holy Grail for cancer? Ann Transl Med. 2013; 1(1): 1

PubMed Abstract | Publisher Full Text | Free Full Text

37. Bonovas S: Statins: do they have a potential role in cancer prevention and modifying cancer-related outcomes? Drugs. 2014; 74(16): 1841-8. PubMed Abstract | Publisher Full Text

38. Gazzerro P, Proto MC, Gangemi G, et al.: Pharmacological actions of statins: a critical appraisal in the management of cancer. Pharmacol Rev. 2012; 64(1) $102-46$.

PubMed Abstract | Publisher Full Text

39. Gronich N, Rennert G: Beyond aspirin-cancer prevention with statins, metformin and bisphosphonates. Nat Rev Clin Oncol. 2013; 10(11): 625-42. PubMed Abstract | Publisher Full Text

40. F Lytras T, Nikolopoulos G, Bonovas S: Statins and the risk of colorectal cancer: an updated systematic review and meta-analysis of $\mathbf{4 0}$ studies. World $J$ Gastroenterol. 2014; 20(7): 1858-70.

PubMed Abstract | Publisher Full Text | Free Full Text | F1000 Recommendation

41. F Bansal D, Undela K, D'Cruz S, et al.: Statin use and risk of prostate cancer: a meta-analysis of observational studies. PLoS One. 2012; 7(10): e46691. PubMed Abstract | Publisher Full Text | Free Full Text | F1000 Recommendation

42. F Singh S, Singh AG, Singh PP, et al.: Statins are associated with reduced sk of esophageal cancer, particularly in patients with Barrett's esophagus: a systematic review and meta-analysis. Clin Gastroenterol Hepatol. 2013; 11(6): 620-9.

PubMed Abstract | Publisher Full Text | Free Full Text | F1000 Recommendation

43. Dale $\mathrm{KM}$, Coleman $\mathrm{Cl}$, Henyan NN, et al:: Statins and cancer risk: a meta-analysis. JAMA. 2006; 295(1): 74-80.

PubMed Abstract | Publisher Full Tex

44. F Nielsen SF, Nordestgaard BG, Bojesen SE: Statin use and reduced cancer-related mortality. N Engl J Med. 2012; 367(19): 1792-802. PubMed Abstract | Publisher Full Text | F1000 Recommendation

45. Quinn BJ, Kitagawa H, Memmott RM, et al.: Repositioning metformin for cancer prevention and treatment. Trends Endocrinol Metab. 2013; 24(9): 469-80. PubMed Abstract | Publisher Full Text

46. F DeCensi A, Puntoni M, Goodwin P, et al:: Metformin and cancer risk in diabetic patients: a systematic review and meta-analysis. Cancer Prev Res (Phila). 2010; 3(11): 1451-61.

PubMed Abstract | Publisher Full Text | F1000 Recommendation

47. F Evans JM, Donnelly LA, Emslie-Smith AM, et al:: Metformin and reduced risk of cancer in diabetic patients. BMJ. 2005; 330(7503): 1304-5

PubMed Abstract | Publisher Full Text | Free Full Text | F1000 Recommendation

48. F Sehdev A, Shih YC, Vekhter B, et al.: Metformin for primary colorectal cancer prevention in patients with diabetes: a case-control study in a US population. Cancer. 2015; 121(7): 1071-8.

PubMed Abstract | Publisher Full Text | F1000 Recommendation

49. F Zhang ZJ, Zheng ZJ, Shi R, et al:: Metformin for liver cancer prevention in patients with type 2 diabetes: a systematic review and meta-analysis. J Clin Endocrinol Metab. 2012; 97(7): 2347-53.

PubMed Abstract | Publisher Full Text | F1000 Recommendation

50. World Cancer Research Fund/American Institute for Cancer Research. Food, Nutrition, Physical Activity, and the Prevention of Cancer: a Global Perspective. Washington DC: AICR, 2007.

Reference Source
51. Albanes D, Heinonen OP, Huttunen JK, et al.: Effects of alpha-tocopherol and beta-carotene supplements on cancer incidence in the Alpha-Tocopherol Beta-Carotene Cancer Prevention Study. Am J Clin Nutr. 1995; 62(6 Suppl): 1427S-1430S

PubMed Abstract

52. Omenn GS, Goodman GE, Thornquist MD, et al:: Effects of a combination of beta carotene and vitamin $A$ on lung cancer and cardiovascular disease. $N$ Engl $J$ Med. 1996; 334(18): 1150-5.

PubMed Abstract | Publisher Full Text

53. F Cortés-Jofré M, Rueda JR, Corsini-Muñoz G, et al.: Drugs for preventing lung cancer in healthy people. Cochrane Database Syst Rev. 2012; 10: CD002141. PubMed Abstract | Publisher Full Text | F1000 Recommendation

54. World Cancer Research Fund/American Institute for Cancer Research. Food, Nutrition, Physical Activity, and the Prevention of Cancer: a Globa Perspective. Washington DC: AICR, 2007. Updated 2014 Reference Source

55. Papas AM: Antioxidant Status, Diet, Nutrition and Health. Boca Raton, FL: CRC Press, 1999 Reference Source

56. The effect of vitamin $E$ and beta carotene on the incidence of lung cancer and other cancers in male smokers. The Alpha-Tocopherol, Beta Carotene Cancer Prevention Study Group. N Engl J Med. 1994; 330(15): 1029-35. PubMed Abstract | Publisher Full Text

57. Kim YI: Folate and colorectal cancer: an evidence-based critical review. Mol Nutr Food Res. 2007; 51(3): 267-92.

PubMed Abstract | Publisher Full Text

58. World Cancer Research Fund/American Institute for Cancer Research. Food, Nutrition, Physical Activity, and the Prevention of Cancer: a Global Perspective. Washington DC: AICR, 2007. Updated 2012.

Reference Source

59. World Cancer Research Fund/American Institute for Cancer Research. Food research and the prevention of cancer: a global perspective. Washington, DC: American Institute for Cancer Research. 1997.

Reference Source

60. F Wang L, Sesso HD, Glynn RJ, et al:: Vitamin E and C supplementation and risk of cancer in men: posttrial follow-up in the Physicians' Health Study II randomized trial. Am J Clin Nut. 2014; 100(3): 915-23.

PubMed Abstract | Publisher Full Text | Free Full Text | F1000 Recommendation

61. Zhang X, Giovannucci E: Calcium, vitamin D and colorectal cancer chemoprevention. Best Pract Res Clin Gastroenterol. 2011; 25(4-5): 485-94. PubMed Abstract | Publisher Full Text

62. IARC Working Group on Vitamin D. Vitamin D and cancer/a report of the IARC Working Group on Vitamin D. IARC Working Group Reports. Lyon, France, 2008; 5. Reference Source

63. Heinonen OP, Albanes D, Virtamo J, et al.: Prostate cancer and supplementation with alpha-tocopherol and beta-carotene: incidence and mortality in a controlled trial. J Natl Cancer Inst. 1998; 90(6): 440-6. PubMed Abstract | Publisher Full Text

64. Virtamo J, Pietinen P, Huttunen JK, et al.: Incidence of cancer and mortality following alpha-tocopherol and beta-carotene supplementation: a postintervention follow-up. JAMA. 2003; 290(4): 476-85. PubMed Abstract | Publisher Full Text

65. F Lippman SM, Klein EA, Goodman PJ, et al.: Effect of selenium and vitamin $\mathrm{E}$ on risk of prostate cancer and other cancers: the Selenium and Vitamin $\mathrm{E}$ Cancer Prevention Trial (SELECT). JAMA. 2009; 301(1): 39-51. PubMed Abstract | Publisher Full Text | Free Full Text | F1000 Recommendation

66. F Klein EA, Thompson IM Jr, Tangen CM, et al.: Vitamin E and the risk f prostate cancer: the Selenium and Vitamin E Cancer Prevention Trial (SELECT). JAMA. 2011; 306(14): 1549-56.

PubMed Abstract | Publisher Full Text | Free Full Text | F1000 Recommendation

67. Bennett LL, Rojas S, Seefeldt T: Role of antioxidants in the prevention of cancer. J Exp Clin Med. 2012; 4(4): 215-222. Publisher Full Text

68. World Cancer Research Fund/American Institute for Cancer Research. Food, Nutrition, Physical Activity, and the Prevention of Cancer: a Global Perspective. Washington DC: AICR, 2007. Updated 2011. Reference Source

69. Chan AT, Giovannucci EL: Primary prevention of colorectal cancer. Gastroenterology. 2010; 138(6): 2029-2043.e10. PubMed Abstract | Publisher Full Text | Free Full Text

70. F Carroll C, Cooper K, Papaioannou D, et al:: Supplemental calcium in the chemoprevention of colorectal cancer: a systematic review and meta-analysis. Clin Ther. 2010; 32(5): 789-803.

PubMed Abstract | Publisher Full Text | F1000 Recommendation

71. Rayman MP: The importance of selenium to human health. Lancet. 2000; 356(9225): 233-41.

PubMed Abstract | Publisher Full Text

72. F Marshall JR, Tangen CM, Sakr WA, et al:: Phase III trial of selenium to prevent prostate cancer in men with high-grade prostatic intraepithelia neoplasia: SWOG S9917. Cancer Prev Res (Phila). 2011; 4(11): 1761-9. PubMed Abstract | Publisher Full Text | Free Full Text | F1000 Recommendation

73. Romagnolo DF, Selmin OI: Flavonoids and cancer prevention: a review of the evidence. J Nutr Gerontol Geriatr. 2012; 31(3): 206-38.

PubMed Abstract | Publisher Full Text 
74. Mursu J, Nurmi T, Tuomainen T, et al.: Intake of flavonoids and risk of cancer in Finnish men: The Kuopio Ischaemic Heart Disease Risk Factor Study. Int J Cancer. 2008; 123(3): 660-3. PubMed Abstract | Publisher Full Text

75. Cutler GJ, Nettleton JA, Ross JA, et al.: Dietary flavonoid intake and risk of cancer in postmenopausal women: the lowa Women's Health Study. Int J Cancer. 2008; 123(3): 664-71. PubMed Abstract | Publisher Full Text | Free Full Text

76. Peterson J, Lagiou $P$, Samoli $E$, et al:: Flavonoid intake and breast cancer risk: a case--control study in Greece. Br J Cancer. 2003; 89(7): 1255-9. PubMed Abstract | Publisher Full Text | Free Full Text

77. Wang L, Lee IM, Zhang SM, et al:: Dietary intake of selected flavonols, flavones, and flavonoid-rich foods and risk of cancer in middle-aged and older women. Am J Clin Nutr. 2009; 89(3): 905-12.

PubMed Abstract | Publisher Full Text | Free Full Text

78. Rossi M, Bosetti C, Negri E, et al.: Flavonoids, proanthocyanidins, and cancer risk: a network of case-control studies from Italy. Nutr Cancer. 2010; 62(7): 871-7. PubMed Abstract | Publisher Full Text

79. Hui C, Qi X, Qianyong Z, et al.: Flavonoids, flavonoid subclasses and breast cancer risk: a meta-analysis of epidemiologic studies. PLoS One. 2013; 8(1): e54318.

PubMed Abstract | Publisher Full Text | Free Full Text

80. F Jin $\mathrm{H}$, Leng $\mathrm{Q}$, Li C: Dietary flavonoid for preventing colorectal neoplasms. Cochrane Database Syst Rev. 2012; 8: CD009350.

PubMed Abstract | Publisher Full Text | F1000 Recommendation

81. Hwang YW, Kim SY, Jee SH, et al.: Soy food consumption and risk of prostate cancer: a meta-analysis of observational studies. Nutr Cancer. 2009; 61(5): 598-606.

PubMed Abstract | Publisher Full Text

82. Lall RK, Syed DN, Adhami VM, et al:: Dietary polyphenols in prevention and treatment of prostate cancer. Int J Mol Sci. 2015; 16(2): 3350-76. PubMed Abstract | Publisher Full Text | Free Full Text

83. Ting H, Deep G, Agarwal C, et al.: The strategies to control prostate cancer by chemoprevention approaches. Mutat Res. 2014; 760: 1-15. PubMed Abstract | Publisher Full Text | Free Full Text

84. National Institutes of Health State-of-the-Science Panel. National Institutes of Health State-of-the-Science Conference Statement: multivitamin/mineral supplements and chronic disease prevention. Am J Clin Nutr. 2007; 85(1): 257S-264S. PubMed Abstract
85. F Macpherson H, Pipingas A, Pase MP: Multivitamin-multimineral supplementation and mortality: a meta-analysis of randomized controlled trials. Am J Clin Nutr. 2013; 97(2): 437-44.

PubMed Abstract | Publisher Full Text | F1000 Recommendation

86. Cancer vaccines. National Cancer Institute. Assessed June 2015. Reference Source

87. Liu JK: Anti-cancer vaccines - a one-hit wonder? Yale J Biol Med. 2014; 87(4): 481-9.

PubMed Abstract | Free Full Text

88. Hepatitis B Vaccine. Hepatitis B Foundation. Doylestown, Pennsylvania. Updated 2013-02-26. Assessed June 2015. Reference Source

89. Monographs on the Evaluation of Carcinogenic Risks to Humans: HPV. IARC Scientific Publications No. 90. International Agency for Cancer Research. Lyon, 2005 Reference Source

90. Muñoz N, Bosch FX, de Sanjosé S, et al.: Epidemiologic classification of human papillomavirus types associated with cervical cancer. N Engl J Med. 2003 348(6): 518-27.

PubMed Abstract | Publisher Full Text

91. HPV vaccines. Centers for Disease Control and Prevention. Assessed June 2015 Reference Source

92. Herrero R, González P, Markowitz LE: Present status of human papillomavirus vaccine development and implementation. Lancet Oncol. 2015; 16(5): e206-16. PubMed Abstract | Publisher Full Text

93. Steward WP, Brown K: Cancer chemoprevention: a rapidly evolving field. Br J Cancer. 2013; 109(1): 1-7.

PubMed Abstract | Publisher Full Text | Free Full Text

94. Serrano D, Lazzeroni M, Bonanni B: Cancer chemoprevention: Much has been done, but there is still much to do. State of the art and possible new approaches. Mol Oncol. 2015; 9(5): 1008-17.

PubMed Abstract | Publisher Full Text

95. Landis-Piwowar KR, lyer NR: Cancer chemoprevention: current state of the art Cancer Growth Metastasis. 2014; 7: 19-25. PubMed Abstract | Publisher Full Text | Free Full Text

96. Wu AH, Tseng CC, Van Den Berg D, et al:: Tea intake, COMT genotype, and breast cancer in Asian-American women. Cancer Res. 2003; 63(21): 7526-9. PubMed Abstract 


\section{Open Peer Review}

\section{Current Peer Review Status:}

\section{Editorial Note on the Review Process}

Faculty Reviews are review articles written by the prestigious Members of Faculty Opinions. The articles are commissioned and peer reviewed before publication to ensure that the final, published version is comprehensive and accessible. The reviewers who approved the final version are listed with their names and affiliations.

\section{The reviewers who approved this article are:}

\section{Version 1}

\section{Janusz Jankowski}

University Hospitals Coventry and Warwickshire, University of Warwick, Warwickshire, UK

Competing Interests: No competing interests were disclosed.

\section{Hasan Mukhtar}

School of Medicine and Public Health, Department of Dermatology, University of Wisconsin Medical Science Center, Madison, WI, USA

Competing Interests: No competing interests were disclosed.

\section{Michihiro Mutoh}

Epidemiology and Prevention Division, Research Center for Cancer Prevention and Screening, National Cancer Center, Chuo-ku, Japan

Competing Interests: No competing interests were disclosed.

The benefits of publishing with F1000Research:

- Your article is published within days, with no editorial bias

- You can publish traditional articles, null/negative results, case reports, data notes and more

- The peer review process is transparent and collaborative

- Your article is indexed in PubMed after passing peer review

- Dedicated customer support at every stage

For pre-submission enquiries, contact research@f1000.com 